\title{
QUALITY OF SPECIALTY COFFEE: BALANCE BETWEEN AROMA, FLAVOUR AND BIOLOGICALLY ACTIVE COMPOUND COMPOSITION: REVIEW
}

\author{
Ilze Laukalēja, Zanda Krūma \\ Latvia University of Life Sciences and Technologies, Latvia \\ ilze.laukaleja@gmail.com
}

\begin{abstract}
Specialty coffee, according to Specialty Coffee Association of America (SCAA) standards, is coffee which has been standardized from the coffee plantation process until its delivery to the consumer, in compliance with all quality standards, to highlight the characteristics of the beverage. With increasing coffee consumption, more attention is focused not only on the flavour and texture of the drink, but also on the impact of coffee on health. The beneficial effects of coffee on human health are mainly based on a wide range of biologically active components. The coffee composition of the biologically active compounds and flavour compounds are influenced differently by almost all technological processes. The aim of this review was to summarize recent scientific developments about composition of aroma, flavour and biologically active compounds in specialty coffee and evaluate the best possibilities to balance health promoting and flavour attributes. Specialty coffee mainly focuses on fruity, floral, sweet and acidic notes in coffee, which are opposite to phenolic compound aroma characteristics during roasting process. In conclusion, roasting temperature significantly influences all biologically active compounds and important aroma, flavour volatiles in coffee. All compound concentration, except coffee melanoidins, decreases during roasting process. Light-medium roast level could provide stability among floral, fruity aroma, flavour notes and biologically active compounds (phenolic compounds and coffee melanoidins) in coffee.
\end{abstract}

Key words: specialty coffee, volatile compounds, biologically active compounds, coffee quality.

\section{Introduction}

Coffee consumption is significantly increasing each year. With increasing coffee consumption, consumers pay more attention to the quality of the coffee - taste, appearance and information about coffee origin, post-harvesting process, roast level, grind size and preferred brewing technique. The highest quality coffee is characterized by a fruity, nutty flavour and pleasant acidity, bitterness that defines the composition of the specialty coffee volatile compounds (Sepúlveda et al., 2016).

Specialty coffee is coffee which has been standardized from the coffee plantation process until its delivery to the consumer, in compliance with all quality standards, to highlight the characteristics of the beverage. The main criterion for specialty coffee is to provide the taste, aroma and texture qualities to the coffee beverage (Sepúlveda et al., 2016; Kim et al., 2018;).

With increasing coffee consumption, more attention is focused not only on the flavour and texture of the drink but also on the impact of coffee on health. The beneficial effects of coffee on human health are mainly based on a wide range of biologically active compounds (Caprioli et al., 2014; Nuhu, 2014).

Specialty coffee quality is focused on the texture, aroma and taste of the drink, but focusing mainly on the flavour compounds, the balance of biologically active compounds is disrupted. The coffee composition of the biologically active compounds and flavour compounds are influenced differently by almost all technological processes (Vignoli et al., 2014). The aim of this review was to summarize recent scientific developments about composition of aroma, flavour and biologically active compounds in specialty coffee and evaluate the best possibilities to balance health promoting and flavour attributes.

\section{Materials and Methods}

This research was proceeded by using the monographic method, summarizing actual researches of specialty coffee chemical composition. This review summarizes differences between volatile and biologically active compound composition in specialty coffee, and theological processes, which influences them most.

\section{Results and Discussion}

\section{Non volatile compound composition of coffee}

Chemical composition of lipid, protein and carbohydrates in coffee contains the precursors function for developing flavour, aroma composition of the coffee beverage. It is also one of the reasons why specialty standards are significantly higher for green coffee. Specialty coffee standards for green coffee quality (environmental factors, post-harvesting process) can ensure high sensory qualities to roasted coffee and coffee brew (Joët et al., 2010; Somporn et al., 2011).

One of the main chemical components is coffee lipid (coffee oil). In Coffea arabica coffee lipid content varies between $15 \%$, but in Coffea canephora only 10\% from dry matter (Aleriana et al., 2011). Lipid composition in coffee mostly consists of triglycerides, diterpene alcohols and esterified sterols. The diterpenes kahweol and cafestol are the main 
coffee oils. C. arabica coffee has higher kahweol and cafestol concentration than C. canephora. Both diterpenes are relatively rare in free form and are mainly found in esterified form with fatty acids, for example, linoleic acid, which also gives the bitterness to coffee. It has been reported that fatty acids composition in specialty coffee is important to bring mouthfeel characteristics (body, texture) and essential aroma, flavour compounds to the coffee beverage. Saturated fatty acids have proven positive correlation with sensory qualities of specialty coffee. Coffee with higher content of stearic and arachidic fatty acid shows more intense body, texture of coffee, but coffee with higher myristic fatty acid content has a positive correlation with acidity (Fassio et al., 2017). Unsaturated fatty acids have negative correlation with sensory criteria like aroma, flavour, acidity, body, which are important specialty coffee criteria. Unsaturated fatty acids tend to oxidize and the oxidation process leads to unpleasant aroma and characteristics (Aleriana et al., 2011; Figueiredo et al., 2015; Fassio et al., 2017). Fatty acids influence coffee quality. Also, it is crucial in a storage process - the oxidation process creates 'rested coffee flavour' and increases free fatty acid content, one of the reasons could be associated with elaidic acid content in coffee (Figueiredo et al., 2015; Fassio et al., 2017).

Carbohydrates make the largest part of coffee bean chemical composition ( $\sim 60 \%$ of green coffee bean dry matter). Carbohydrates have one of the crucial roles in coffee quality - forming aroma, flavour and colour in the roasting process. The most important compounds are sucrose and polysaccharides. In green coffee beans polysaccharides, like arabinogalactans, galactomannans, create an insoluble polysaccharide complex, whose function is to straighten the cell walls of coffee bean (Fischer et al., 2001; Steen et al., 2017). In the process of roasting, these qualities are reduced because of polysaccharide degradation and fallowing formation of reduced sugars like mannose, arabinose or glucose. Reduction of sugars further forms a wide range of aroma compounds (Fischer et al., 2001; Geromel et al., 2008; Figueiredo et al., 2015; Toledo et al., 2016). C.arabica contains 5 - 9\% sucrose and $48-55 \%$ total polysaccharides, while C.canephora contains 4 - 7\% sucrose and 38 - 48\% total polysaccharides. Sucrose content in coffee positively correlates with acidity and sweetness (Figueiredo et al., 2013; Fassio et al., 2017). It has been proven that coffee with higher organic acid content and sucrose content has a higher final sensory score of coffee quality. In sucrose degradation process, reducing sugars are formed, which are important elements in Maillard reaction (Borém et al., 2016). Sucrose composition in coffee bean is highly associated with coffee cherry maturation. The slower maturation process of the coffee fruit is associated with formation of many complex sugars. It is one of the reasons why Specialty coffee standards are the highest for harvesting and post harvesting process (Geromel et al., 2008; Joët et al., 2010).

Coffee proteins in C.arabica are in a slightly lower concentration than in C. cenphora $(10-13 \%$ from dry matter). Coffee proteins consist of amino acids and peptides. In C. arabica and C. cenphora are three main amino acids - glutamic acid, aspartic acid and $\gamma$-aminobutyric acid (GABA) (Rendón, Salva, \& Bragagnolo, 2014; Bressanello et al., 2017). All amino acid concentration rapidly decreases after roasting temperature over $180^{\circ} \mathrm{C}$. In the roasting process amino acids react with reducing sugars (Maillard reaction) and form pyrroles, pyridines, pyrazines, but reducing sugars can also react with free amino acids (Strecker reaction) forming aldehydes (Toci et al., 2013). Coffee proteins work as precursors for coffee aroma, flavor, it is because of protein-aroma compound or proteinflavor compound binding. Proteins have a positive correlation with phenolic compounds and coffee mealnoidins, which can be explained by protein and phenolic compound involvement in coffee melanoidin formation (Coelho et al., 2014).

Melanoidins are formed in roasting process as Maillard reaction final products (Coelho et al., 2014). There has been reported that polysaccharides, chlorogenic acid and proteins are involved in melanoidin formation (Moreira et al., 2012). Melanoidins have a positive influence to sensory qualities of coffee and positive impact to health. Melanoidins have an important role in coffee crema (layer of foam found on the surface of a shot of espresso coffee) formation in espresso coffee. Coffee melanoidins are associated with bitter sweet roast flavor, which is increasing with the roasting process. A higher melanoidins concentration tends to decrease unpleasant sulfury/roasty flavor of coffee beverage, which is explained by coffee melanoidins and thiol covalent binding (Quintanilla-Casas et al., 2015; Kim et al., 2018).

Trigonelline concentration is higher in C. arabica than in C. cenphora. Trigonelline has a positive correlation with sensory qualities as acidity, sweetness and flavour (Fassio et al., 2017; Worku et al., 2018). In the roasting process trigonelline degradates to pyrroles, pyrazines, which have positive aroma, flavour qualities (Oliveira Fassio et al., 2016).

\section{Aroma compound composition of coffee}

It has been proven that green coffee has approximately 100 different volatile compounds and 950 volatile compounds in roasted coffee. However, only about 20 of them can significantly affect the formation of flavour and aroma (Kim et al., 2018). 
Important aroma, flavour compounds in specialty coffee

\begin{tabular}{|l|l|l|l|}
\hline \multicolumn{1}{|c|}{ Classes } & \multicolumn{1}{c|}{ Compounds } & \multicolumn{1}{c|}{ Type of aroma } & \multicolumn{1}{c|}{ References } \\
\hline Furans & 2-furfurylthiol & roasted coffee & Piccino et al., 2014; Somporn et al., 2011 \\
\hline Aldehydes & (e,e)-nona-2,4-dienal & citrus (fruity) & Piccino et al., 2014 \\
\hline Aldehydes & 3-methylbutanal & chocolate & Mestdagh et al., 2014; Piccino et al., 2014 \\
\hline Pyrazines & 2-ethyl-3,5-dimethylpyrazine & hazelnut & Mondello et al., 2005; Piccino et al., 2014 \\
\hline Aldehydes & 2-phenylacetaldehyde & floral (rose) & Piccino et al., 2014 \\
\hline Pyrazines & 2,3-dimethyl-5-ethylpyrazine & hazelnut, cacao & Yang et al., 2016; Piccino et al., 2014 \\
\hline Furanones & $\begin{array}{l}\text { 4-hydroxy-2,5-dimethyl-3(2h)- } \\
\text { furanone }\end{array}$ & strawberry, caramel & Piccino et al., 2014; Toledo et al., 2016 \\
\hline Alcohols & linalool & floral, fruity & Piccino et al., 2014; Toledo et al., 2016 \\
\hline
\end{tabular}

Specialty coffee high demands on the quality of sensory factors is confirmed in several studies, showing that specialty coffee detects almost all 20 volatile compounds that significantly affect the aroma composition (highlighting chocolate, fruit, caramel flavour notes). These coffee quality defining characteristics have positive association with coffees which have the closest quality standards to the specialty coffee guidelines. For example, Alex and co-authors (2016) analysed the relationship between three different regions of coffee in Brazil and sensory quality attributes, and the aroma of fruit, caramel and pleasant acidity was found in coffee whose quality standards were the highest in accordance with the SCAA standards.

Generally, the volatile compounds found in coffee are furans, ketones, phenols, aldehydes, acids, esters, pyridines, anhydrides, and nitrogen and sulfur compounds. According to research data, furans and their compounds are the largest class after concentration, but pyrazines, aldehydes and ketones are classes with the most commonly known compounds, some of which have strong odorant properties (Moon \& Shibamoto, 2009; Piccino et al., 2014; Yang et al., 2016; Steen et al., 2017).

Piccino and co-authors (2014) analysing aromatic composition of coffee identified 107 compounds from which 22 compounds were chosen as potent odorants, for example, 2-furfurylthiol, 3-methylbutanal, 1-ethyl3-methylbenzene. In Table 1, important aroma, flavour compounds are summarized in specialty coffee.

Compounds with fruity flavour odour are the most sensitive to environmental factors of plantation, harvesting and post-harvesting process. Linalool in roasted coffee can be as flavour precursors, bringing floral, fruity notes to roasted specialty coffee if the formation process of coffee cherries is done accurately, but by harvesting immature coffee beans linalool concentration only increases in green coffee bean storage as a result of oxidation process (Mondello et al., 2005; Piccino et al., 2014; Toledo et al., 2016).

Ketones and aldehydes are characterized by flower, fruit flavour and pleasant acidity. Fruit and flower notes are not associated with roasted coffee, but the latest research notes regularities that the increase in the quality of coffee increases proportionally volatile compounds with fruit and flower notes (Piccino et al., 2014; Borém et al., 2016; Steen et al., 2017). Almond, cherry flavour is associated with benzaldehyde, strawberry and citrus flavour with 2-phenylacetaldehyde (Piccino et al., 2014). If the fermentation process is not controlled during coffee bean harvesting and the roasting process, the desired aldehyde and ketone compounds can easily convert into spirits and negatively change the aroma of the coffee composition. Aldehydes and ketones are among the most sensitive compounds and their changes influence sensory evaluation; therefore, the concentration of some aldehydes and ketones is an indicator of the quality of coffee quality.

Volatile aromas are obtained during the roasting process, for example, 2-methoxy-4-vinylphenol (a bitter cloves aroma) is formed from two types of reactions involving the decarboxylation of 4-vinylguaiacol as ferric acid (Moreira et al., 2012; Cheong et al., 2013). Consequently, when ferric acid decreases, the concentration of volatile compounds in roasted coffee increases. Specialty coffee mainly focuses on fruit, floral and sweet acidic notes in coffee, which are opposite to phenolic compound aroma notes (Piccino et al., 2014).

The sweetness and acidity is highly influenced by organic acid balance - malic, citric and phosphoric acid. Malic and citric acids have positive correlation with sucrose content in coffee (Jham et al., 2007; Borém et al., 2016). Malic acid has apple flavour, but a sensory assessment has often been characterized also with plum, pears and apricot flavour notes and has been associated with a sensory quality, especially, with a pleasant acidity (Borém et al., 2016). Citric acid is 
known for citric fruit flavour notes (lemon, lime), and phosphoric acid is associated with a grapefruit. Lactic acid and hexanoic acid have buttery, creamy flavour and provide pleasant acidity (Jham et al., 2007; Moon \& Shibamoto, 2009). Various research have proven that the amount of chlorogenic acid is lower in highquality roasted coffee than in low-quality roasted coffee (Coelho et al., 2014; Tolessa et al., 2016). Chlorogenic acid in the process of roasting is converted into lactones which give the coffee a pleasant bitter taste (Moreira et al., 2012; Cheong et al., 2013). If the roasting process continues from light - medium roast to medium-dark chlorogenic acid lactones are transformed to phenylindanes which give strong bitter, burning taste (Yang et al., 2016; Tolessa et al., 2016). However, studies have been found to confirm that it is possible to provide high-quality coffee without losing significant levels of chlorogenic acid. For highquality coffee, it is necessary to ensure that defects are turned off before roasting and chooses a light-medium degree of roasting. The exclusion of defects reduces the removal of unfavorable derivatives of chlorogenic acid, but in light-medium roasted coffee, compounds that highlight pleasant bitterness (Zanin et al., 2016). Oliveira Fassio and co-authors (2016) confirmed that roasted coffee from Catigua cultivar can contain high final sensory score and higher 5-caffeoylquinic acid concentration.

Furans, mostly associated with caramel and a spicy flavour at light roasted coffee and bitter, spicy flavour with increasing roast and serving temperature, for example, furaneol is associeted with sweet caramel, but only in light roasted coffee (Somporn et al., 2011; Cheong et al., 2013; Bressanello et al., 2017). Overall, furans have high odor thresholds, but high furan concentration sets them as important flavours for the sensory quality. Except 2-Furfurylthiol is highly important compound for volatile composition of coffee, because of very low odor thresholds and high concentration in roasted coffee, with chocolate, roasted flavour notes (Moon \& Shibamoto, 2009; Piccino et al., 2014; Kim et al., 2018).

Pyrazine compounds are characterized by nutty flavour in roasted coffee and herbal flavour in green coffee. The quality of coffee has a significant effect on the pyrazine compounds, since some of the compounds have a pleasant nutty flavor, but some of the compounds have distinct odor characteristics with a grass, wood flavour that affects the overall sensory rating (Yang et al., 2016; Piccino et al., 2014). Specialty coffee has a distinctly higher amount of pyrazine compounds with positive flavour notes, such as ethylpyrazine with peppermint flavour, 3-ethyl2,5-dimethyl-5-ethylpyrazine and 2,3-dimethyl-5ethylparazine with a coconut flavor (Piccino et al., 2014; Steen et al., 2017).

\section{Biologically active compounds}

Health benefits from coffee consumption are associated with a wide range of biologically active compounds. Biologically active compounds in coffee are mainly caffeine, diterpenes and phenolic compounds. Moderate coffee consumption is associated with reduced mortality, cardiovascular disease risk, depression and migraine (Somporn et al., 2011; Nuhu, 2014).

Chlorogenic acid has been demonstrated both in vitro and in vivo studies that the antioxidant activity and the ability to reduce the oxidative stress in disease cells. For example, in vitro study, chlorogenic acid form coffee eliminates DNA damage in breast cancer cells (Nuhu, 2014). Caffeine is equated with a reduced risk of developing metabolic syndrome based on the fact that caffeine boosts metabolism, energy consumption, promotes lipid oxidation and lipolysis and promotes the thermogenesis of the body (Ludwig et al., 2012; Nuhu, 2014). Danish scientists concluded that cafestol can improve insulin secretion when glucose is added and increases glucose uptake in muscle cells at the same level as exposure antidiabetic medicines (Carman et al., 2014; Nuhu, 2014).

Trigonelline has shown hypoglycaemic, neuroprotective and antibacterial effects. In vitro studies have shown that trigonelline is able to stimulate glucose metabolism and use in the synthesis of ATP in hepatic cells (Ludwig et al., 2012). Melanoidins in coffee brew have antibacterial activity against gramnegative and gram-positive bacteria (Moreira et al., 2012). The research author concluded that melanoidins have probiotic function and could regulate gut micro biota, promoting good gut bacteria growth (Carman et al., 2014). The antibacterial and antioxidant functions can be explained by the melanoidin composition of insoluble polysaccharides and phenolic compounds. Polysaccharides function as fiber elements and phenolic compounds as antioxidants, though coffee melanoidins have a lower antioxidant activity than phenolic compounds like chlorogenic acid. It is proven that antioxidant activity stays at the highest point in light-medium roast level, when coffee melanoidins start to form and the chlorogenic acid is still at high concentration (Coelho et al., 2014; Vignoli et al., 2014).

\section{Technical process influence on chemical composition}

It is known that every physical-chemical process, especially post-harvesting, roasting, brewing process, can influence differently chemical composition of coffee. Table 2 shows the most influential technical processes to specialty coffee composition. The harvesting and post-harvesting process is proven to set the basic chemical composition to the green coffee bean and also to the coffee beverage (Rendón et al., 2014; Figueiredo et al., 2015; Fassio et al., 2017). 
Technical process influence on biologically active and volatile compounds

\begin{tabular}{|c|c|c|c|}
\hline Compound & Type of aroma & Technical process & References \\
\hline \multicolumn{4}{|c|}{ Biologically active compounds } \\
\hline Chlorogenic acid & bitter & $\begin{array}{l}(\downarrow) * \text { increasing roast temperature } \\
(\downarrow) \text { increasing serving temperature }\end{array}$ & $\begin{array}{l}\text { (Jeszka-Skowron et al., } \\
\text { 2016; Steen et al., 2017) }\end{array}$ \\
\hline Trigonelline & bitter & $(\downarrow)$ increasing roast temperature & (Vignoli et al., 2014) \\
\hline Caffeine & bitter & $(\downarrow)$ increasing roast temperature & $\begin{array}{l}\text { Moon \& Shibamoto, 2009; } \\
\text { Somporn et al., } 2011\end{array}$ \\
\hline Coffee mellanoids & bittersweet & $(\uparrow)^{* *}$ increasing roast temperature & $\begin{array}{l}\text { Coelho et al., 2014; Vignoli } \\
\text { et al., } 2014\end{array}$ \\
\hline Kahweol, cafestol & bitter & $(\downarrow)$ increasing roast temperature & $\begin{array}{l}\text { Aleriana et al., 2011; } \\
\text { Kitzberger et al., 2013; } \\
\text { Sridevi \& Giridhar, 2016 } \\
\end{array}$ \\
\hline \multicolumn{4}{|c|}{ Important specialty coffee volatile compounds } \\
\hline (E,E)-nona-2,4-dienal & fruity & $\begin{array}{l}(\uparrow) \text { longer coffee extraction period } \\
(\downarrow) \text { increasing roast temperature } \\
(\downarrow) \text { increasing serving temperature }\end{array}$ & Piccino et al., 2014 \\
\hline (E)- $\beta$-damascenone & floral (rose) & $\begin{array}{l}(\uparrow) \text { longer coffee extraction period } \\
(\downarrow) \text { increasing roast temperature } \\
(\downarrow) \text { increasing serving temperature } \\
\end{array}$ & $\begin{array}{l}\text { Mestdagh et al., 2014; } \\
\text { Piccino et al., } 2014\end{array}$ \\
\hline 3-Methylbutanal & chocolate & $(\downarrow)$ increasing roast temperature & $\begin{array}{l}\text { Mondello et al., 2005; Steen } \\
\text { et al., } 2017\end{array}$ \\
\hline 2-phenylacetaldehyde & $\begin{array}{l}\text { floral, fruity (rose, } \\
\text { citrus) }\end{array}$ & $\begin{array}{l}(\uparrow) \text { longer coffee extraction period } \\
(\downarrow) \text { increasing roast temperature } \\
(\downarrow) \text { increasing serving temperature }\end{array}$ & $\begin{array}{l}\text { Mestdagh et al., 2014; } \\
\text { Piccino et al., } 2014\end{array}$ \\
\hline Malic acid & apple, pear & $\begin{array}{l}(\uparrow) \text { increasing plant growth altitude } \\
(\downarrow) \text { increasing serving temperature } \\
\end{array}$ & Borém et al., 2016 \\
\hline $\begin{array}{l}\text { 2,3-dimethyl-5- } \\
\text { ethylparazine }\end{array}$ & coconut & $\begin{array}{l}(\downarrow) \text { increasing roast temperature }(\downarrow) \\
\text { increasing serving temperature }\end{array}$ & $\begin{array}{l}\text { Piccino et al., 2014; Steen et } \\
\text { al., } 2017\end{array}$ \\
\hline
\end{tabular}

$*(\downarrow)$ concentration of compound is decreasing ** $(\uparrow)$ concentration of compound is increasing.

Kahweol and cafestol concentration in C. arabica are increasing with altitude, but $C$. canephora coffee kahweol and cafestol concentration is negatively associated with altitude (Aleriana et al., 2011; Kitzberger et al., 2013; Sridevi \& Giridhar, 2016). Increasing roasting temperature decreases caffeine, chlorogenic acid, trigonelline kahweol and cafestol concentration and decreases all important specialty coffee volatile compounds (Geromel et al., 2008; Somporn et al., 2011; Sridevi \& Giridhar, 2016). Some of phenolic compounds in roasting process are formed in coffee melanoidins, which is the reason why coffee melanoidins concentration is increasing with roasting temperature. Coffee melanoidins have a lower antioxidant activity than phenolic compounds like, chlorogenic acid. It is proven that an antioxidant activity remains at the highest point in light-medium roast level, when coffee melanoidins start to form and the chlorogenic acid is still at high concentration. It also slows down the bitter phenolic compound formation (Coelho et al., 2014; Vignoli et al., 2014).
From volatile compound point of view fruity, floral flavour notes with pleasant acidity is more in coffee with serving temperature between $31{ }^{\circ} \mathrm{C}-$ $44{ }^{\circ} \mathrm{C}$, phenylethanal (floral flavour) and 3-hexanone (sweet citric flavour) is highly volatile at $45{ }^{\circ} \mathrm{C}$ in coffee serving temperature (Kim et al., 2018). But by increasing serving temperature from $44{ }^{\circ} \mathrm{C}$ to $56{ }^{\circ} \mathrm{C}$ chlorogenic acid content is decreasing and forming phenolic compounds with bitter flavour notes (Somporn et al., 2011; Steen et al., 2017; Worku et al., 2018) Also floral, fruity flavour notes could be influenced by extraction time of coffee brew. Mestdagh and co-authors (2014) confirmed that (E)- $\beta$-damascenone, 2-phenylacetaldehyde and (E,E)-nona-2,4-dienal compounds release their aroma flavours slower than compounds with chocolate, roasted flavour notes. It also approves that espresso coffee has a stronger roasted aroma, but filtered coffee presents more fruit, acidity and floral notes to the coffee drink (Mestdagh et al., 2014; Parenti et al., 2014). 


\section{Conclusions}

Correctly choosing post-harvest process and coffee bean maturity could provide a stability in nonvolatile compound composition. Roasting temperature significantly influences all biologically active compounds and important aroma, flavour volatiles in coffee. All compound concentration, except coffee melanoidins, decreases during roasting process. Light-medium roast level could provide stability among floral, fruity aroma, flavour notes and phenolic compounds and coffee melanoidins in coffee.

\section{References}

1. Aleriana, T., Wagemaker, L., Regina, C., Carvalho, L., Borlina, N., Regina, S., \& Guerreiro, O. (2011). Sun protection factor, content and composition of lipid fraction of green coffee beans. Industrial Crops \& Products, 33(2), 469-473. DOI: 10.1016/j.indcrop.2010.10.026.

2. Alex, M. de C., Juliana, C. de R., Tiago, T.R., Andre, D.F., Ramiro, M.R., Antonio, N.G.M., \& Gladyston, R.C. (2016). Relationship between the sensory attributes and the quality of coffee in different environments. African Journal of Agricultural Research, 11(38), 3607-3614. DOI: 10.5897/AJAR2016.11545.

3. Borém, F.M., Figueiredo, L.P., Ribeiro, F.C., Taveira, J.H.S., Giomo, G.S., \& Salva, Tt.J.G. (2016). The relationship between organic acids, sucrose and the quality of specialty coffees. African Journal of Agricultural Research, 11(8), 709-717. DOI: 10.5897/AJAR2015.10569.

4. Bressanello, D., Liberto, E., Cordero, C., Rubiolo, P., Pellegrino, G., Ruosi, M.R., \& Bicchi, C. (2017). Coffee aroma: Chemometric comparison of the chemical information provided by three different samplings combined with GC-MS to describe the sensory properties in cup. Food Chemistry, 214(Supplement C), 218-226. DOI: 10.1016/j.foodchem.2016.07.088.

5. Caprioli, G., Cortese, M., Maggi, F., Minnetti, C., Odello, L., Sagratini, G., \& Vittori, S. (2014). Quantification of caffeine, trigonelline and nicotinic acid in espresso coffee: the influence of espresso machines and coffee cultivars. International Journal of Food Sciences and Nutrition, 65(4), 465-469. DOI: 10.3109/09637486.2013.873890.

6. Carman, A.J., Dacks, P.A., Lane, R.F., Shineman, D.W., \& Fillit, H.M. (2014). Current evidence for the use of coffee and caffeine to prevent age-related cognitive decline and Alzheimer's disease. Journal of Nutrition, Health and Aging, 18(4), 383-392. DOI: 10.1007/s12603-014-0021-7.

7. Cheong, M.W., Tong, K.H., Ong, J.J.M., Liu, S.Q., Curran, P., \& Yu, B. (2013). Volatile composition and antioxidant capacity of Arabica coffee. Food Research International, 51(1), 388-396. DOI: 10.1016/j. foodres.2012.12.058.

8. Coelho, C., Ribeiro, M., Cruz, A.C.S., Domingues, M.R.M., Coimbra, M.A., Bunzel, M., \& Nunes, F.M. (2014). Nature of phenolic compounds in coffee melanoidins. Journal of Agricultural and Food Chemistry, 62(31), 7843-7853. DOI: 10.1021/jf501510d.

9. Oliveira Fassio, L., Malta, M., Carvalho, G., Liska, G., de Lima, P., \& Pimenta, C. (2016). Sensory Description of Cultivars (Coffea Arabica L.) Resistant to Rust and Its Correlation with Caffeine, Trigonelline, and Chlorogenic Acid Compounds. Beverages, 2(1), 1-12. DOI: 10.3390/beverages2010001.

10. Fassio, L.O., Malta, M.R., Carvalho, G.R., Liska, G.R., Lima, P.M., Nadaleti, D.H.S., ... Pimenta, C.J. (2017). Fatty Acids Profile of Coffea arabica L. Resistant to Leaf Rust Grown in Two Environments of Minas Gerais, Brazil. Journal of Agricultural Science, 9(12), 88-98. DOI: 10.5539/jas.v9n12p88.

11. Fassio, L.O., Malta, M.R., Liska, G.R., Alvarenga, S.T., Sousa, M.M.M., Farias, T.R.T., \& Pereira, R.G.F.A. (2017). Sensory Profile and Chemical Composition of Specialty Coffees from Matas de Minas Gerais, Brazil. Journal of Agricultural Science, 9(9), 78-93. DOI: 10.5539/jas.v9n9p78.

12. Figueiredo, L.P., Borém, F.M., Cirillo, M.Â., Ribeiro, F.C., Giomo, G.S., \& Salva, T.D.J.G. (2013). The Potential for High Quality Bourbon Coffees From Different Environments. Journal of Agricultural Science, 5(10) 87-98. DOI: 10.5539/jas.v5n10p87.

13. Figueiredo, L.P., Borem, F.M., Ribeiro, F.C., Gimo, G.S., Taveira, J.H., \& Malta, M.R. (2015). Fatty acid profiles and parameters of quality of specialty coffees produced in different Brazilian regions. African Journal of Agricultural Research, 10(35), 3484-3493. DOI: 10.5897/AJAR2015.9697.

14. Fischer, M., Reimann, S., Trovato, V., \& Redgwell, R.J. (2001). Polysaccharides of green Arabica and Robusta coffee beans. Carbohydrate Research, 330(1), 93-101. DOI: 10.1016/S0008-6215(00)00272-X.

15. Geromel, C., Ferreira, L., Davrieux, F., Guyot, B., Ribeyre, F., Santos-Scholz, M.B., ... Marraccini, P. (2008). Effects of shade on the development and sugar metabolism of coffee (Coffea arabica L.) fruits. Plant Physiology and Biochemistry, 46(5-6), 569-579. DOI: 10.1016/j.plaphy.2008.02.006.

16. Jeszka-Skowron, M., Sentkowska, A., Pyrzyńska, K., \& De Peña, M.P. (2016). Chlorogenic acids, caffeine content and antioxidant properties of green coffee extracts: influence of green coffee bean preparation. European Food Research and Technology, 242(8), 1403-1409. DOI: 10.1007/s00217-016-2643-y. 
17. Jham, G.N., Fernandes, S.A., Garcia, C.F., \& Palmquist, D. (2007). Comparison of GC and HPLC for quantification of organic acids in two jaboticaba (Myrciaria) fruit varieties. Quimica Nova, 30(7), 15291534. DOI: $10.1590 /$ S0100-40422007000700006.

18. Joët, T., Salmona, J., Laffargue, A., Descroix, F., \& Dussert, S. (2010). Use of the growing environment as a source of variation to identify the quantitative trait transcripts and modules of co-expressed genes that determine chlorogenic acid accumulation. Plant, Cell and Environment, 33(7), 1220-1233. DOI: 10.1111/j.1365-3040.2010.02141.x.

19. Kim, S.-Y., Ko, J.-A., Kang, B.-S., \& Park, H.-J. (2018). Prediction of key aroma development in coffees roasted to different degrees by colorimetric sensor array. Food Chemistry, 240, 808-816. DOI: 10.1016/J. FOODCHEM.2017.07.139.

20. Kitzberger, C.S.G., Scholz, M.B. dos S., Pereira, L.F.P., Vieira, L.G.E., Sera, T., Silva, J.B.G.D., \& Benassi, M. de T. (2013). Diterpenes in green and roasted coffee of Coffea arabica cultivars growing in the same edapho-climatic conditions. Journal of Food Composition and Analysis, 30(1), 52-57. DOI: 10.1016/j. jfca.2013.01.007.

21. Ludwig, I.A., Sanchez, L., Caemmerer, B., Kroh, L.W., De Peña, M.P., \& Cid, C. (2012). Extraction of coffee antioxidants: Impact of brewing time and method. Food Research International, 48(1), 57-64. DOI: 10.1016/j.foodres.2012.02.023.

22. Mestdagh, F., Davidek, T., Chaumonteuil, M., Folmer, B., \& Blank, I. (2014). The kinetics of coffee aroma extraction. Food Research International, 63, 271-274. DOI: 10.1016/j.foodres.2014.03.011.

23. Mondello, L., Costa, R., Tranchida, P.Q., Dugo, P., Presti, M. Lo, Festa, S., ... Dugo, G. (2005). Reliable characterization of coffee bean aroma profiles by automated headspace solid phase microextractiongas chromatography-mass spectometry with the support of a dual-filter mass spectra library. Journal of Separation Science, 28(9-10), 1101-1109. DOI: 10.1002/jssc.200500026.

24. Moon, J.K., \& Shibamoto, T. (2009). Role of roasting conditions in the profile of volatile flavor chemicals formed from coffee beans. Journal of Agricultural and Food Chemistry, 57(13), 5823-5831. DOI: 10.1021/ jf901136e.

25. Moreira, A.S.P., Nunes, F.M., Domingues, M.R., \& Coimbra, M.A. (2012). Coffee melanoidins: structures, mechanisms of formation and potential health impacts. Food \& Function, 3(9), 903-915. DOI: 10.1039/ c2fo30048f.

26. Nuhu, A.A. (2014). Bioactive Micronutrients in Coffee: Recent Analytical Approaches for Characterization and Quantification. ISRN Nutrition, 2014, 1-13. DOI: 10.1155/2014/384230.

27. Parenti, A., Guerrini, L., Masella, P., Spinelli, S., Calamai, L., \& Spugnoli, P. (2014). Comparison of espresso coffee brewing techniques. Journal of Food Engineering, 121(1), 112-117. DOI: 10.1016/j. jfoodeng.2013.08.031.

28. Piccino, S., Boulanger, R., Descroix, F., \& Sing, A.S.C. (2014). Aromatic composition and potent odorants of the "specialty coffee" brew "Bourbon Pointu" correlated to its three trade classifications. Food Research International, 61, 264-271. DOI: 10.1016/j.foodres.2013.07.034.

29. Quintanilla-Casas, B., Dulsat-Serra, N., Cortés-Francisco, N., Caixach, J., \& Vichi, S. (2015). Thiols in brewed coffee: Assessment by fast derivatization and liquid chromatographyehigh resolution mass spectrometry. LWT - Food Science and Technology, 64(2), 1085-1090. DOI: 10.1016/j.lwt.2015.07.010.

30. Rendón, M.Y., De Jesus Garcia Salva, T., \& Bragagnolo, N. (2014). Impact of chemical changes on the sensory characteristics of coffee beans during storage. Food Chemistry, 147, 279-286. DOI: 10.1016/j. foodchem.2013.09.123.

31. Sepúlveda, W.S., Chekmam, L., Maza, M.T., \& Mancilla, N.O. (2016). Consumers' preference for the origin and quality attributes associated with production of specialty coffees: Results from a cross-cultural study. Food Research International, 89, 997-1003. DOI: 10.1016/j.foodres.2016.03.039.

32. Somporn, C., Kamtuo, A., Theerakulpisut, P., \& Siriamornpun, S. (2011). Effects of roasting degree on radical scavenging activity, phenolics and volatile compounds of Arabica coffee beans (Coffea arabica L. cv. Catimor). International Journal of Food Science and Technology, 46(11), 2287-2296. DOI: 10.1111/j.1365-2621.2011.02748.x.

33. Sridevi, V., \& Giridhar, P. (2016). Variations in Diterpenes-Cafestol and Kahweol Content in Beans of Robusta Coffee Grown at Different Altitudes. Proceedings of the National Academy of Sciences India Section B - Biological Sciences, 86(2), 291-297. DOI: 10.1007/s40011-014-0429-1.

34. Steen, I., Waehrens, S.S., Petersen, M.A., Münchow, M., \& Bredie, W.L.P. (2017). Influence of serving temperature on flavour perception and release of Bourbon Caturra coffee. Food Chemistry, 219, 61-68. DOI: 10.1016/j.foodchem.2016.09.113. 
35. Toci, A.T., Neto, V.J.M.F., Torres, A.G., \& Farah, A. (2013). Changes in triacylglycerols and free fatty acids composition during storage of roasted coffee. LWT - Food Science and Technology, 50(2), 581-590. DOI: 10.1016/j.lwt.2012.08.007.

36. Toledo, P.R.A.B., Pezza, L., Pezza, H.R., \& Toci, A.T. (2016). Relationship Between the Different Aspects Related to Coffee Quality and Their Volatile Compounds. Comprehensive Reviews in Food Science and Food Safety, 15(4), 705-719. DOI: 10.1111/1541-4337.12205.

37. Tolessa, K., Rademaker, M., De Baets, B., \& Boeckx, P. (2016). Prediction of specialty coffee cup quality based on near infrared spectra of green coffee beans. Talanta, 150, 367-374. DOI: 10.1016/j. talanta.2015.12.039.

38. Vignoli, J.A., Viegas, M.C., Bassoli, D.G., \& Benassi, M. de T. (2014). Roasting process affects differently the bioactive compounds and the antioxidant activity of arabica and robusta coffees. Food Research International, 61, 279-285. DOI: 10.1016/j.foodres.2013.06.006.

39. Worku, M., de Meulenaer, B., Duchateau, L., \& Boeckx, P. (2018). Effect of altitude on biochemical composition and quality of green arabica coffee beans can be affected by shade and postharvest processing method. Food Research International, 105(November), 278-285. DOI: 10.1016/j.foodres.2017.11.016.

40. Yang, N., Liu, C., Liu, X., Degn, T.K., Munchow, M., \& Fisk, I. (2016). Determination of volatile marker compounds of common coffee roast defects. Food Chemistry, 211, 206-214. DOI: 10.1016/j. foodchem.2016.04.124.

41. Zanin, R.C., Corso, M.P., Kitzberger, C.S.G., Scholz, M.B. dos S., \& Benassi, M. de T. (2016). Good cup quality roasted coffees show wide variation in chlorogenic acids content. LWT - Food Science and Technology, 74, 480-483. DOI: 10.1016/j.lwt.2016.08.012. 